\title{
OPEN Quantification of Phytophthora infestans population densities and their changes in potato field soil using real-time PCR
}

\author{
Hisashi Osawa ${ }^{1,5 \bowtie}$, Nobuyuki Suzuki ${ }^{1}$, Seishi Akino ${ }^{2 \bowtie}$, Hiromichi Araki ${ }^{3}$, Kenji Asano ${ }^{4}$, \\ Kotaro Akai ${ }^{4}$ \& Norio Kondo ${ }^{2}$
}

Tuber infection of Phytophthora infestans often occurs at harvest. However, it is difficult to accurately estimate the population densities of $P$. infestans in soil, especially Japanese soil. In the present study, $P$. infestans DNA was extracted from soil samples using a modified CTAB-bead method and quantified using real-time PCR to accurately, rapidly and easily estimate the $P$. infestans population densities in upland soils in Japan. $P$. infestans was well quantified in eleven types of soil samples, including nine types of upland soils in Japan, that were artificially inoculated with a zoosporangia suspension. The amounts of $P$. infestans DNA estimated by the real-time PCR were proportional to the inoculum densities. In the non-controlled experimental potato field, $P$. infestans population densities in soil corresponded to the development of symptoms and were correlated with the number of lesions on the potato foliage. These results imply that the proposed real-time PCR assay is suitable for the estimation or monitoring of $P$. infestans population densities in upland soils in Japan. The population densities at the ridge bottoms were larger than those at any other location in commercial potato fields. These results were similar to those of a previous report using a bioassay. Moreover, a correlation between DNA quantity and inoculum potential was observed. In conclusion, the real-time PCR assay developed in this study is suitable for indirect estimation of the inoculum potential of $P$. infestans.

Various kinds of pathogenic microorganisms cause potato tuber rot; however, tuber rot caused by Phytophthora infestans is common in the potato industry as tuber blight. Tuber infection occurs during the growth period ${ }^{1,2}$, at harvest ${ }^{3}$ and handling ${ }^{4}$. Moreover, surface injury at harvest and the presence of $P$. infestans sporangia or blighted plant material are important factors affecting the incidence of potato storage rot in Japanese potato production ${ }^{5}$. Thus, the severity or amount of potato tuber rot in storage facilities can be predicted by estimating the population densities of $P$. infestans in field soils at harvest.

In previous studies, bioassays using healthy leaflet or tuber slices were mainly applied to quantify the population densities of $P$. infestans in soil ${ }^{2,6,7}$. However, bioassays have the disadvantages of requiring (1) equalized conditions and (2) an incubation period. Thus, we applied a real-time PCR assay that can accurately and rapidly provide quantitative results and has a wide dynamic range. DNA extraction from soil can often be difficult, and the addition of skim milk to the extraction buffer has been shown to promote the extraction of DNA from volcanic ash soil ${ }^{8}$. Quantification of the population densities of soil-borne plant pathogens has already been reported ${ }^{9}$, even for $P$. infestans $s^{10,11}$. However, naturally infested soils were not quantified in these previous studies; one soil type was usually studied following inoculation with the pathogens. In Japan, volcanic ash soil, such as andosol, is widespread and used to cultivate potatoes, and is known to increase the difficulty of extracting DNA from soil due to the absorption of DNA by soil colloids ${ }^{8}$. Thus, there are no reports on how $P$. infestans population densities in soil fluctuate in actual potato production fields. Additionally, we have to examine whether there are positive correlations between the amounts of DNA quantified by real-time PCR and foliage symptom development, such as the number of lesions.

\footnotetext{
${ }^{1}$ Graduate School of Agriculture, Hokkaido University, Kita-ku Kita 9 Nishi 9, Sapporo 060-8589, Japan. ${ }^{2}$ Research Faculty of Agriculture, Hokkaido University, Kita-ku Kita 9 Nishi 9, Sapporo 060-8589, Japan. ${ }^{3}$ Potato Research Center, Calbee Potato Inc., 3-23, Minami, Higashimemuro, Memuro, Hokkaido 082-0006, Japan. ${ }^{4}$ Hokkaido Agricultural Research Center, NARO, 9-4, Shinseiminami, Memuro, Hokkaido 082-0081, Japan. ${ }^{5}$ Present address: Hokkaido Agricultural Research Center, NARO, 1, Hitsujigaoka, Toyohira-ku, Sapporo, Hokkaido 062-8555, Japan. ${ }^{\boxplus}$ email: osawah315@affrc.go.jp; sakino@res.agr.hokudai.ac.jp
} 


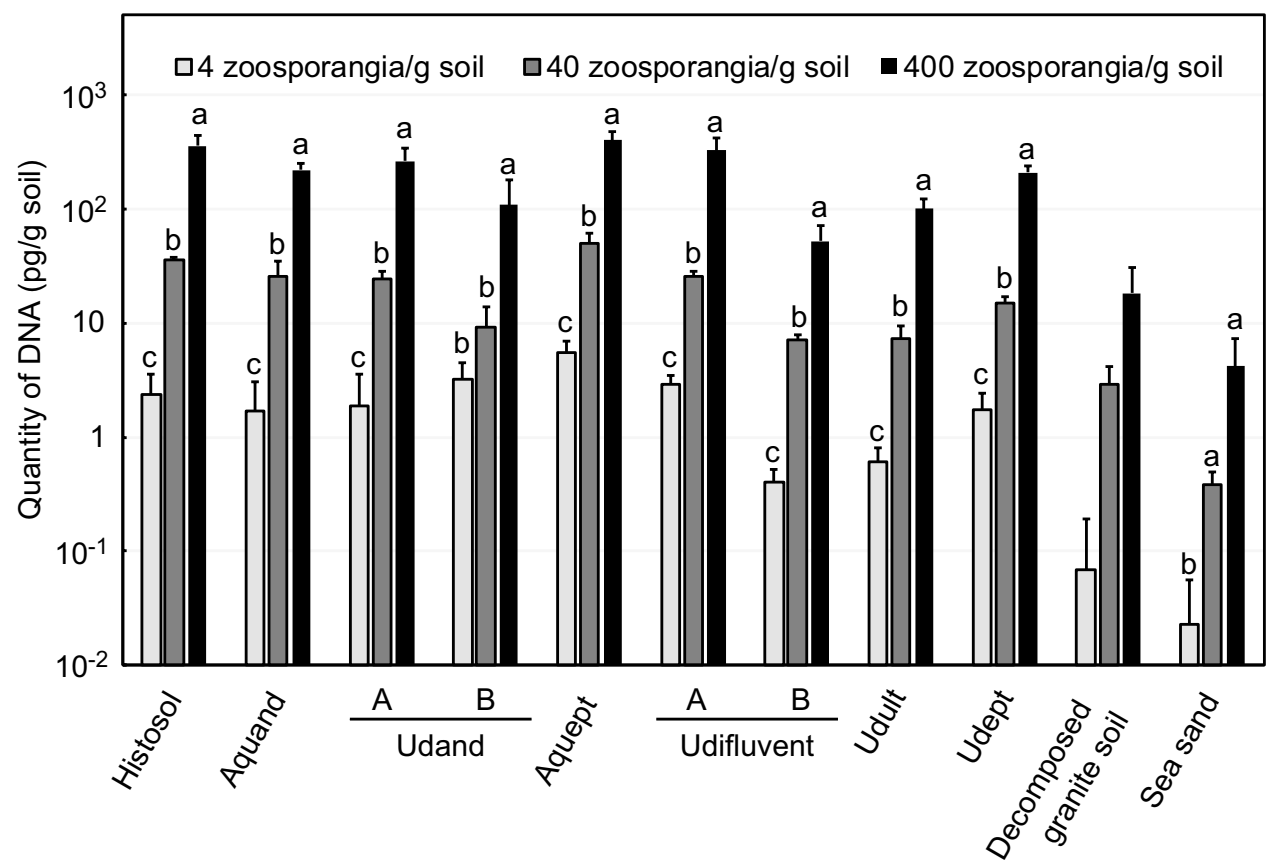

Figure 1. Quantities of $P$. infestans DNA determined using real-time PCR. No P. infestans DNA was detected in the negative control plots. Bars indicate the standard deviation. Means $(n=3)$ with different letters in the same soil type differed significantly according to post hoc tests $(p<0.05$, Tukey's test, Games-Howell test or SteelDwass test).

If this real-time PCR method is established, we will be able to detect inoculum concentrations in sample soils by using real-time PCR instead of a bioassay to accurately predict the risk of disease development. This real-time PCR assay will be applicable to various methods of disease control. For example, the possibilities or severity of potato storage rot may be predicted by estimating the $P$. infestans population density in soil immediately before harvesting. Moreover, we might apply this assay to soil diagnosis before planting. The objectives of this study are (1) to develop a quantitative real-time PCR assay method using various kinds of upland soils in Japan, (2) to estimate the $P$. infestans population densities in potato fields using real-time PCR assay, and (3) to verify the relationship between quantities of $P$. infestans DNA and inoculum potential for further research to reduce potato storage rot in storage facilities.

\section{Results}

Quantification of the population density of $\boldsymbol{P}$. infestans in inoculated soils. From each of the 11 soil types inoculated with the pathogen, DNA was detected in proportion to the densities of the inoculum, while no amplification was found in negative control samples (Fig. 1, Supplementary Fig. S1 online) as well as in a preliminary experiment ${ }^{12}$. Even low densities in soil samples containing approximately 4 zoosporangia/g soil (2 zoosporangia/tube) were well quantified; the quantities of DNA were approximately $1 \mathrm{pg} / \mathrm{g}$ soil (10 fg/ $\mu \mathrm{L})$. However, in decomposed granite soil and sea sand, smaller amounts of DNA were quantified. Additionally, in udifluvent B and an udult, slightly smaller amounts of DNA were quantified than in any other upland soils. However, almost the same amounts of DNA were quantified if soils contained the same numbers of $P$. infestans zoosporangia.

The DNA quantities were reflected in the population densities. When the inoculum density was 10 times higher, approximately 10 times more DNA was detected. All soil types showed significant differences according to one-way analyses of variance (ANOVA) (histosol, aquand, udand A, udand B, aquept, udifluvent A, udifluvent B, udult and udept: $p<0.01$; sea sand: $p=0.01$ ) or Kruskal-Wallis test (decomposed granite soil: $p=0.03$ ). Moreover, according to post hoc tests, the mean amount of $P$. infestans DNA detected in each soil type was significantly different except for that observed in some udand B, decomposed granite soil and sea sand samples (Fig. 1).

Changes in $P$. infestans population densities in non-controlled field soil. We observed symptom development and analysed two types of soils samples, from ridgetops and peripheral areas, in noncontrolled potato fields in the Hokkaido Agricultural Research Center (HARC) during the cultivation period in 2017 and 2018.

In 2017, late blight occurred in the field on 7 July, and some lesions were found for the first time at a sampling location on 28 July. After that, an epidemic occurred on 5 August, and all of the plants had died of late blight by 18 August. The plants were dried by 25 August (Fig. 2). In 2018, late blight was first observed in the field on 6 July and on a sampled plant on 20 July. On 27 July, there were 21.7 lesions/plant; however, the number of lesions on the foliage was decreased due to a heat wave such that only 6 lesions/plant occurred on 5 August. The heat 

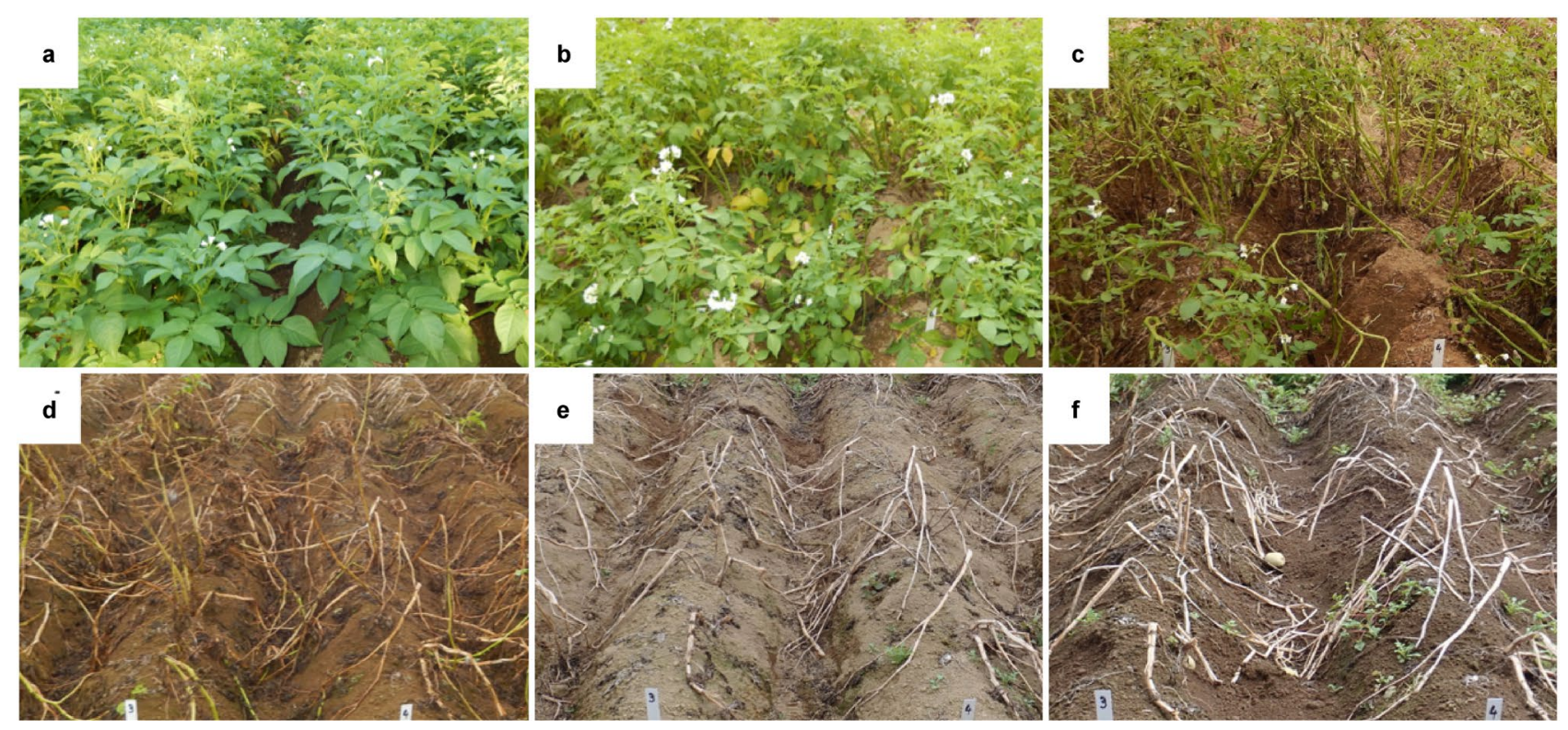

Figure 2. Symptom development at the same place in a non-controlled potato field in 2017. (a) First observation of late blight in the field on 7 July. (b) First observation of late blight on the sampled plants on 28 July. c An epidemic occurred on 5 August. (d) All plants died of late blight by 18 August. (e) The plants were dried by 25 August. (f) The final day of sampling on 15 September.

wave continued for a while, and a second epidemic occurred on 18 August. After the second epidemic, all plants had died by 31 August (Fig. 3). Moreover, a positive correlation $(r=0.41, p=0.03)$ was observed between the quantity of $P$. infestans DNA and the number of lesions.

The quantities of $P$. infestans DNA were small before the outbreak of late blight and when late blight was first observed in the field both in 2017 and 2018. Next, the amounts of DNA increased with foliage symptom development. The amount of DNA in ridgetop soils was $10^{4}-10^{5}$ times larger during the epidemic than when the disease was first observed. After the epidemic, the amounts of DNA decreased with the death and drying of the foliage. There was a small amount of DNA in the ridgetop soil one month after foliage drying in 2017. Most ridgetop samples had larger amounts of DNA than the soil samples from the tuber periphery. This phenomenon was remarkable in 2017 (Fig. 4). Obviously blighted tubers, however, were not found in the sampling sites.

Quantities of $P$. infestans DNA and inoculum potential in commercial field soils. The quantities of DNA were larger in field A than in fields B or C. Soil samples from ridge bottoms contained especially large amounts of DNA. In field A, inoculum potentials were also large, while field B or C showed smaller inoculum potentials than field A (Fig. 5). Moreover, a positive correlation $(r=0.88, p=0.02)$ was observed between the quantity of $P$. infestans DNA and inoculum potential.

The amount of DNA quantified in the tuber periphery soil samples was larger than that in ridgetop soil samples. These results were different from the results of the non-controlled field tests described above. However, the inoculum potentials of the tuber periphery samples were smaller than those of ridgetop samples. Blighted tubers were not found in the sampling sites.

\section{Discussion}

We modified the reported DNA extraction methods using a commercial DNA extraction kit: the cetyl trimethylammonium bromide (CTAB) method ${ }^{13}$ with the addition of skim milk to prevent the absorption of DNA and a bead beating method ${ }^{14}$. In this report, this method is named the modified CTAB-bead method. The proposed real-time PCR assay may be suitable for the quantification of $P$. infestans population densities, at least in Japanese upland soils, because $P$. infestans DNA from various kinds of upland soils was well quantified, and there were no false positives in the negative control plots. Thus, we conclude that the $P$. infestans population density can be represented by the quantity of DNA determined using real-time PCR. One udifluvent and udult soil quantified slightly small amounts of DNA, and there were small differences among soil types at the same population densities. However, this should not be of great consequence because the differences compared with the other upland soils are within tenfold; thus, these small differences are likely due to the soil characteristics. A previous study reported that no single method of cell lysis or purification is appropriate for all soils ${ }^{15}$. Thus, the proposed realtime PCR assay is available to quantify the pathogen densities in soils such that most soil samples containing 4-400 zoosporangia/g soil plots except decomposed granite soil and sea sand were quantified as approximately $1-100 \mathrm{pg} / \mathrm{g}$ soil. Although this method can be used to quantify P. infestans DNA levels in soil, not all soil samples containing the same number of zoosporangia yielded similar results, as the amount of DNA absorbed was dependent on the soil type. Thus, a calibration curve may be required when a new soil type is tested in which a zoosporangia suspension or P. infestans DNA is added to nondiseased soil. Regarding decomposed granite soil 

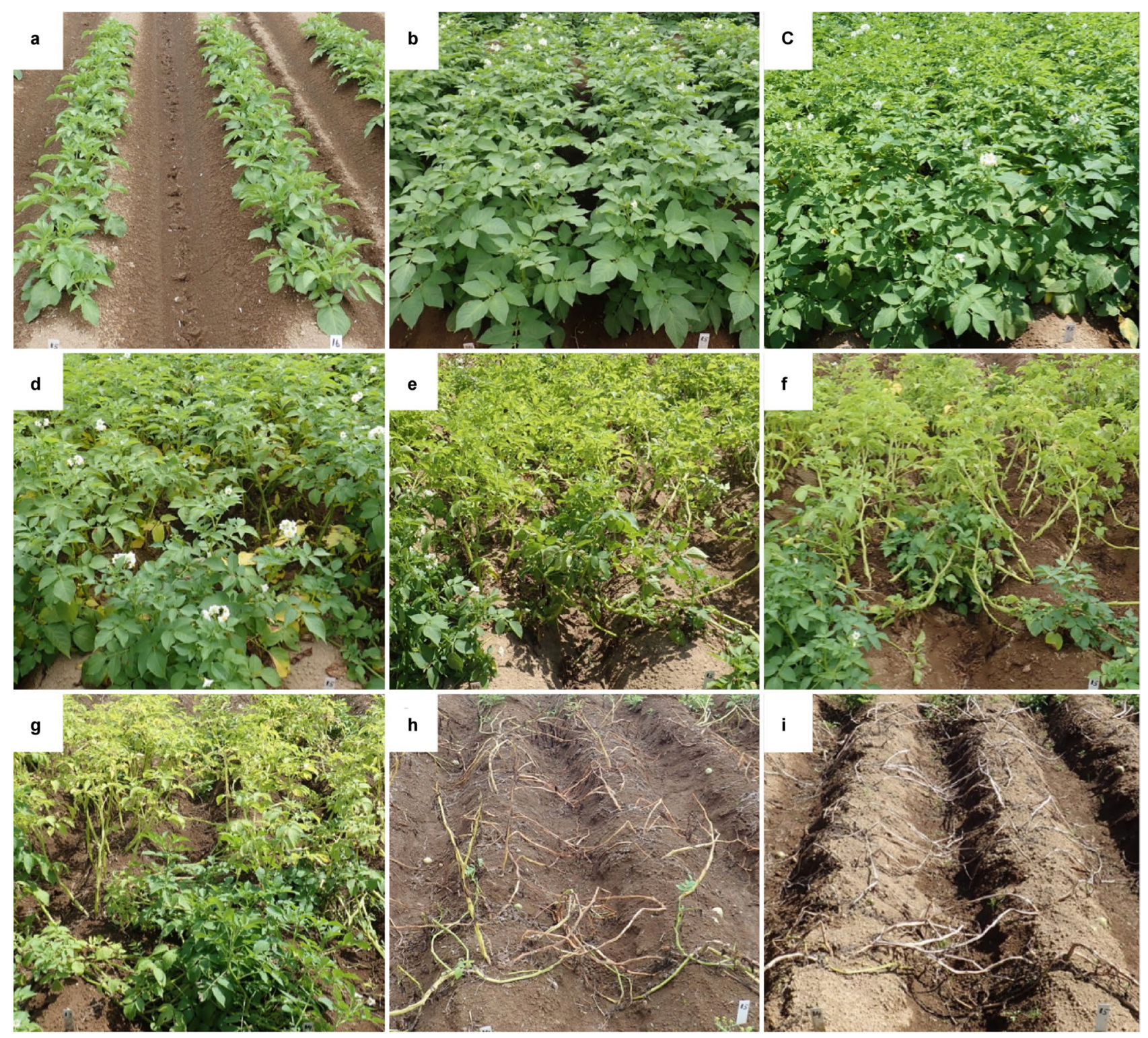

Figure 3. Symptom development at the same place in a non-controlled potato field in 2018. (a) Before the first observation of late blight in a field on 15 June. (b) First observation of late blight in the field on 6 July. (c) First observation of late blight on the sampled plants on 20 July. (d) The number of lesions increased on 27 July. (e) The number of lesions decreased due to a heat wave on 3 August. (f) Most infested leaves were dried and senesced by 25 August. (g) An epidemic occurred on 18 August. (h) All plants died of late blight by 31 August. (i) The plants were dried by 25 August.

and sea sand, which are not upland soils and not suitable for potato cultivation, the reason for the small DNA quantities may be that a large amount of DNA is absorbed onto silica under $\mathrm{Na}^{+}$- or $\mathrm{Ca}^{2+}$-rich conditions ${ }^{16}$. If the soil type is sandy or clayey, the DNA quantities may be smaller than those in other soil types. For further development of this method, the addition of an internal control, such as GFP-induced plasmid DNA ${ }^{17}$, to correct the raw data might be effective. Additionally, changing the glass beads used in this method to zirconia or iron beads may also be effective due to the powerful homogenization and lower amount of DNA absorption achieved with the latter two bead types. However, these improvements may be unnecessary because the proposed assay has a small detection limit such that samples containing only 4 zoosporangia/g soil were detected and quantified. Ristaino et al. ${ }^{18}$ reported that real-time LAMP and droplet digital PCR can be used to quantify P. infestans DNA from plant tissue. Compared with these tools, the proposed real-time PCR assay has some advantages, such as a wide dynamic range. For this reason, this assay may be widely applied to upland soils.

This is the first report of the quantification of $P$. infestans population densities in naturally infested soil samples, and changes in the population densities were analysed using real-time PCR. These results also showed that this quantitative method provides reproducible results, because changes in $P$. infestans DNA were correlated with symptom development throughout the growth periods. DNA quantities during the epidemics ( 5 and 18 August 2017 and 2018, respectively) were converted into $P$. infestans population densities in zoosporangia 

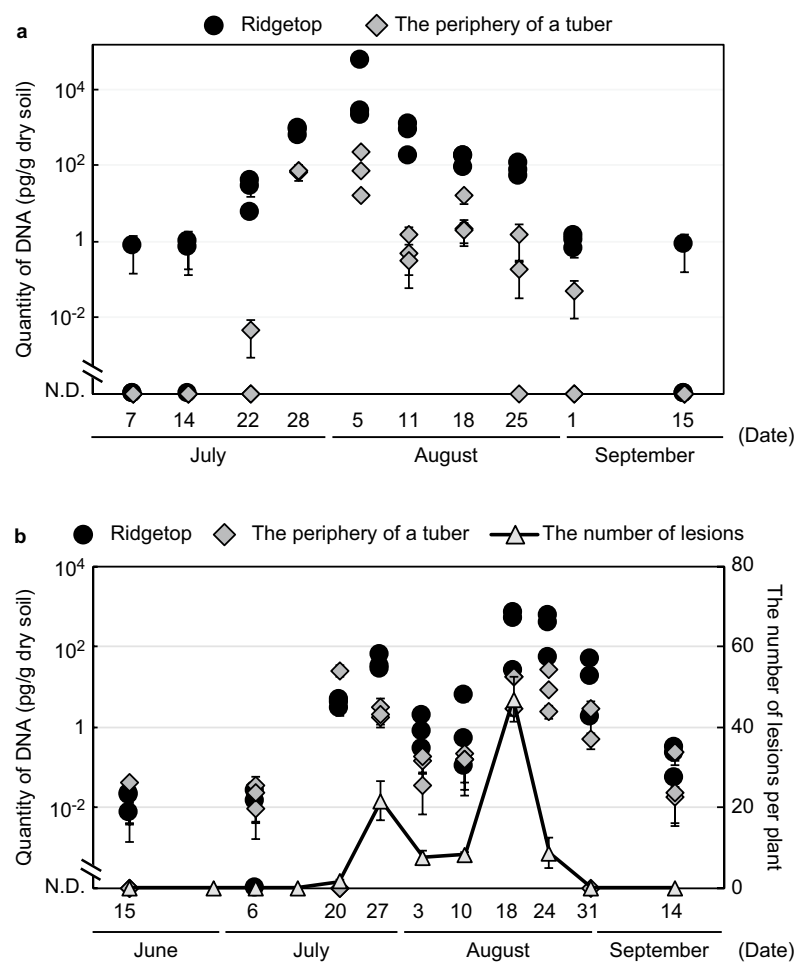

Figure 4. Changes in the quantities of $P$. infestans DNA and the number of foliage lesions. N.D. means not detected. Bars indicate the standard error. (a) 2017 results. (b) 2018 results.

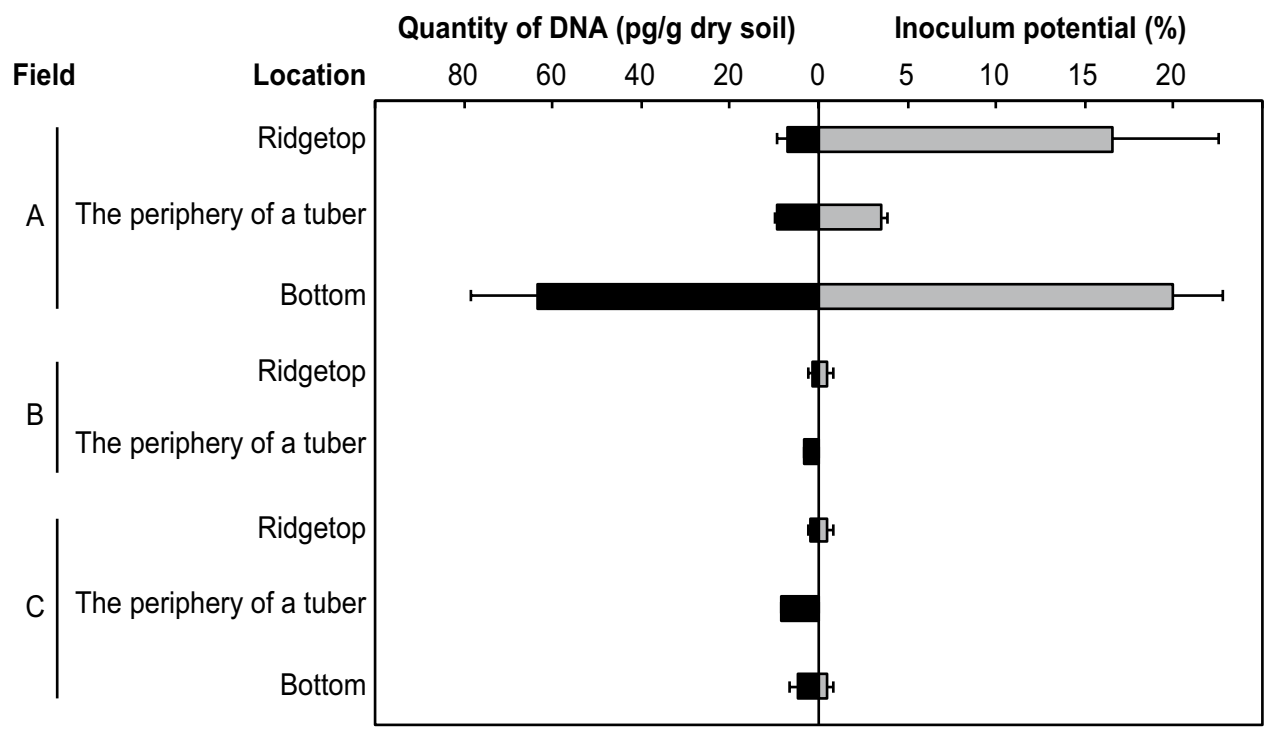

Figure 5. Quantities of $P$. infestans DNA and inoculum potential from soils in commercial fields. Bars indicate the standard error. Fields A, B, and C indicate separate potato fields in the Tokachi region, Hokkaido, Japan.

equivalents based on the results obtained for udant B (experimental field, HARC), as shown in Fig. 1; thus, there were approximately $10^{4}-10^{5}$ and $10^{3}-10^{4}$ zoosporangia in the ridgetop soils. These results indicate that a large amount of $P$. infestans existed in the field ridgetop soils where the plants were blighted. Quantified DNA may be from zoosporangia, mycelia, or small residue or free DNA but not from oospores. Because the A1 mating type has been dominant in Japan since $2005^{19}$, sexual reproduction rarely occurs, at least in potato fields. We have not verified the availability of soils containing oospores. In future studies, inoculated soil containing oospores should be tested. However, soils containing $P$. infestans oospores might be quantified using the proposed assay because previous studies reported that soils containing three potato pathogens and oospores of Pythium spp. 
have been quantified using CTAB and bead beating methods ${ }^{20,21}$. If the proposed assay can quantify P. infestans DNA from oospores in soil, we might apply this assay to soil diagnosis before planting.

A previous study reported that the inoculum potentials of soil decreased as foliage lesions became less abundant ${ }^{2}$. Our study corresponds to this previous study because the quantities of $P$. infestans DNA in soil were consistent with foliage symptom development (in 2017 and 2018) and the number of lesions per plant (in 2018). Hence, the proposed real-time PCR method can be an alternative to bioassays and used as a method to quantify the $P$. infestans population density. Bioassays require special knowledge and techniques of plant pathology because researchers have to judge whether inoculated tubers were rotted due to P. infestans. On the other hand, real-time PCR assays are easy and require only minimal knowledge and techniques of molecular biology. In 2018, symptom development stopped from late July to early August due to a heat wave. The DNA quantities were reflected in foliage symptoms, with small quantities of DNA estimated during this period. These results imply that this method is highly sensitive for estimating even weekly population changes. The quantities of DNA were decreased to one-tenth of their former numbers in a week after the desiccation of the foliage. As indicated by the decrease, most $P$. infestans zoospores or zoosporangia cannot survive in/on the soil and quickly die and are degraded by microorganisms and DNase $e^{6,22,23}$. However, if new A2 strains migrated into Japan and oospores were found in field soil, DNA would be detected for a long time even in the noncultivation period. Surprisingly, an infinitesimal quantity of DNA was detected one month after the foliage had disappeared in 2017. This DNA may have been from another plant out of experimental fields or DNA absorbed to some kind of soil material and may persist against DNase ${ }^{24}$.

Figure 5 shows a positive correlation between the quantity of $P$. infestans DNA and the inoculum potential. Thus, the proposed real-time PCR method is suitable for indirect estimation of $P$. infestans inoculum potential. In this analysis, two data sets containing zero values were eliminated as outliers because a zero value in this experiment signifies "below the detection limit"; we cannot determine the exact value. Thus, data sets containing zero values cannot be included in the analysis to evaluate the applicability of the proposed real-time PCR assay instead of the bioassay for estimating inoculum potential. Previous estimation methods, such as bioassays, require an incubation period of approximately 2-3 weeks, expert knowledge of $P$. infestans and incubation space. On the other hand, real-time PCR requires several hours to estimate the population densities, minimal knowledge of molecular biology and no incubation space. For these reasons, we can more easily estimate $P$. infestans inoculum potential with real-time PCR than with bioassays. In the experiments using commercial potato fields, a larger amount of DNA was quantified from ridge bottom soils than from any other location. This result agrees with a previous report that most rainwater was deposited at the bottoms of ridges, and the rainwater contained fewer than 500 zoosporangia when blight was present on the crop ${ }^{25}$. According to this result, soils sampled from the bottom of a ridge are suitable for whole field estimation of $P$. infestans population densities.

In this study, the quantities of DNA and inoculum potentials were larger in field A than in fields B and C. This result suggests that the proposed real-time PCR assay may be suitable for comparison among potato fields. In field A, late blight occurred because farmers could not conduct chemical control due to heavy rain. Field B was a non-controlled commercial field, and incomplete chemical spraying gave rise to a non-controlled spot in field C. Fields B and C were not perfectly managed for preventing late blight; however, some control, such as cultural or chemical control, was performed in some part. On the other hand, field A did not receive control measures at all. This might be why field A had larger DNA quantities and inoculum potentials than fields B and C.

For the results from non-controlled fields, $P$. infestans did not percolate through the soil but instead remained at the surface because most soil samples from ridgetops contained larger amounts of DNA than those from the tuber periphery. A previous study reported that more than half of the tubers in the top $5.1 \mathrm{~cm}$ of soil were blighted, and the population of blighted tubers decreased with increasing depth ${ }^{26}$. We can show the same conclusions using real-time PCR. However, in commercial fields, all soils sampled from the tuber periphery contained larger amounts of DNA and had a lower inoculum potential than those from the ridge surfaces. Rainy and cold conditions (approximately at $13^{\circ} \mathrm{C}$ ) continued from 14 to 18 August 2018, several days before sampling ${ }^{27}$. The weather might have sustained indirect germination, and many zoospores were released and percolated through the soil. However, zoospores are motile for only a short time ${ }^{28}$ and cannot survive for a long time. Thus, much of the quantified DNA was from dead P. infestans or free DNA, and less inoculum potential was found near tubers. Soil samples from ridgetops showed larger inoculum potential than those from the tuber periphery. This may be because ridgetop samples contain a large amount of fresh $P$. infestans from foliage lesions.

In this study, we successfully developed a real-time PCR assay to estimate the P. infestans densities in upland soils, and the proposed assay is available not only for the estimation of population density but also inoculum potential. In the future, this research can provide to a new decision support system for predicting and preventing potato storage rot. The $P$. infestans soil population density is the most important factor influencing potato storage rot. The possibilities or severities of potato storage rot may be predicted by estimating the $P$. infestans population density in soil before harvesting. Previous storage planning suggested that potato storage rot might occur if many foliage lesions occur during the growing season. In this study, most $P$. infestans DNA from foliage lesions degraded within one week. Thus, the possibility and severity of storage rot may be low if the quantity of $P$. infestans DNA immediately before harvesting is small, even if many foliage lesions occur during the growing season. Additionally, the previous quantitative method (bioassay) requires an incubation period of approximately one week or more ${ }^{2,7}$. On the other hand, the real-time PCR assay does not require an incubation period, and it takes only several hours to quantify the P. infestans population density in the sample soil. Potato storage rot may be reduced because the storage plan can be selected accurately and rapidly by using real-time PCR compared with previous methods. For example, tubers harvested from fields harbouring high levels of $P$. infestans DNA can be shipped as soon as possible to prevent potato storage rot. However, many other factors may be involved in the spread of this disease, such as surface injury ${ }^{5}$. A decision support system would allow potato storage companies 
to evaluate and address factors associated with potato storage rot and establish appropriate countermeasures to prevent economic losses.

\section{Methods}

DNA extraction from inoculated soil. First, $\phi 0.5 \mathrm{~mm}$ (ASONE) and $\phi 0.1 \mathrm{~mm}$ (Sigma-Aldrich) glass beads were washed with hydrochloric acid and dried at $180^{\circ} \mathrm{C}$ for $2 \mathrm{~h}$. Then, $0.4 \mathrm{~g}$ of each of 11 types of healthy soils (Supplementary Table 1 online) was added to tubes containing $0.2 \mathrm{~g}$ of $\phi 0.5 \mathrm{~mm}$ glass beads and $0.1 \mathrm{~g}$ of $\phi 0.1 \mathrm{~mm}$ glass beads. A P. infestans isolate (MR1799: available from NARO Genebank, Japan as MAFF247164) was incubated on rye-B agar medium ${ }^{29}$ at $15^{\circ} \mathrm{C}$ for 2 weeks to make a zoosporangia suspension. Zoosporangia suspensions were adjusted to $2.3 \times 10^{3}, 2.3 \times 10^{2}$, and $2.3 \times 10^{1}$ zoosporangia/mL with distilled water. First, $0.5 \mathrm{~g}$ of artificially inoculated soils (approximately 400, 40 and 4 zoosporangia/g soil) was made by adding $100 \mu \mathrm{L}$ of these zoosporangia suspensions to $0.4 \mathrm{~g}$ of soil in a tube. In negative control plots, distilled water was added instead of zoosporangia suspension. Inoculated soils in bead tubes were stored at $-20{ }^{\circ} \mathrm{C}$, and all plots were triplicated.

DNA was extracted from soil samples collected in Japan using a NucleoSpin Plant II kit (Macherey-Nagel) with a modified extraction buffer ( $2 \mathrm{M} \mathrm{NaCl}, 20 \mathrm{mM}$ EDTA-2Na, $100 \mathrm{mM}$ Tris- $\mathrm{HCl}$ (pH 8.0), 2\% CTAB, 2\% polyvinylpyrrolidone $\mathrm{K}-30,12.5 \%$ skim milk, and $7 \mathrm{mg} / \mathrm{L}$ of salmon sperm DNA) following the manufacturer's protocol and that of Sato et al..$^{30}$. Then, $800 \mu \mathrm{L}$ of the extraction buffer was added to the bead tube, and the tubes were heated in a microwave oven $(200 \mathrm{~W}, 10 \mathrm{~s}$, three times). After heating, the samples were homogenized twice at $4.0 \mathrm{~m} / \mathrm{s}$ for $20 \mathrm{~s}$ (FastPrep 24 Instrument, MP Biomedicals). Homogenized samples were centrifuged for $10 \mathrm{~min}$ at $5000 \mathrm{~g}$ at $20^{\circ} \mathrm{C}$. The obtained clear supernatant was purified based on the kit protocol. Finally, a total of $50 \mu \mathrm{L}$ of DNA template per sample was obtained and stored at $-20^{\circ} \mathrm{C}$.

Real-time PCR. Real-time PCR was carried out using a StepOnePlus Real-time PCR system (Applied Biosystems) and Probe qPCR Mix (Takara Bio). The reaction mixture was made in a final volume of $20 \mu \mathrm{L}$ containing $10 \mu \mathrm{L}$ of Probe qPCR mix, $0.3 \mathrm{M}$ of each primer ${ }^{10}, 0.1 \mathrm{M}$ TaqMan probe ${ }^{10}, 0.2 \mathrm{M}$ ROX reference dye and 2 $\mu \mathrm{L}$ of template DNA. PCR was carried out under the recommended conditions $\left(95^{\circ} \mathrm{C}\right.$ for $30 \mathrm{~s},\left(95^{\circ} \mathrm{C}\right.$ for $5 \mathrm{~s}$ and $61^{\circ} \mathrm{C}$ for $\left.30 \mathrm{~s}\right) \times 45$ cycles). As a negative control, distilled water was used instead of template DNA. The genomic DNA of $P$. infestans was adjusted to $0.01,0.1,1,10,100$ and $1000 \mathrm{pg} / \mu \mathrm{L}$ TE using a spectrophotometer (BioSpecnano, Shimadzu) and used as standards. The threshold was determined automatically by StepOne software v.2.1.

Analyses of changes in the $P$. infestans population densities in non-controlled fields. Soil samples were obtained in a non-controlled potato field (cv. Snowden, a typical cultivar in the Tokachi region and known to be susceptible to leaf and tuber blight) (udand) in HARC, Japan, during the cultivation period (July to September) in 2017 and 2018 (Supplementary Table 1 online). Three plants were randomly selected and sampled along with a handful of ridgetop soil. Next, soils from the periphery of tubers (approximately $15 \mathrm{~cm}$ depth from ridgetop) were sampled in the same manner after removing ridgetop soil to prevent contamination of ridgetop soil in the samples. Each sample was mixed evenly and stored at $-20^{\circ} \mathrm{C}$ until DNA extraction. DNA extraction and quantification were carried out using $0.5 \mathrm{~g}$ of soil sample $(n=3)$ in the same method described above. The soil moisture contents were also investigated by drying at $105^{\circ} \mathrm{C}$ for $24 \mathrm{~h}$. In 2018 , the number of foliage lesions on sampled plants was counted $(n=3)$.

Quantification of population densities and inoculum potentials from soils in commercial fields. Soils were sampled in the commercial potato fields A, B and C, where late blight was observed in the Tokachi region, Hokkaido, Japan on 20 August 2018. Soils were sampled from the area around five plants evenly distributed throughout the diseased area and mixed in approximately equal amounts. Locations of soil samples were the same as described above: ridgetops and tuber peripheries. Additionally, surface soils from the bottom of a ridge were sampled in the same manner in fields A and C. After sampling, soils were divided into two groups: one group was used for quantification of the population densities using real-time PCR, and the other group was used for quantification of inoculum potentials using the bioassay described in Sato $^{2}$. Soil samples for real-time PCR were stored at $-20^{\circ} \mathrm{C}$ as soon as possible. The bioassay was carried out on 22 August 2018. After incubation, the number of rotten tuber pieces with $P$. infestans mycelia and zoosporangia observed by stereoscopic microscopy were counted among 100 total pieces per plot. The inoculum potential equation used in this study was as follows: inoculum potential $(\%)=($ the number of rotten tuber pieces $) /($ the number of total tuber pieces $) \times 100$. DNA extraction and real-time PCR were carried out in the same manner described above. Two and three replicates were performed for the bioassay and real-time PCR, respectively.

Statistical analyses. Before statistical analyses, quantities of $P$. infestans DNA were log-transformed, and their normality and equality of variance were checked by Shapiro-Wilk test and Bartlett's test, respectively. To compare the quantity of $P$. infestans DNA in artificially inoculated soil samples, ANOVA was applied for each soil type except for decomposed granite soil and sea sand. For decomposed granite soil, the Kruskal-Wallis test was used instead of ANOVA because the dependent variables were not normally distributed. For sea sand, Welch's ANOVA was employed because the data did not have equality of variance. When the ANOVA result was significant $(p<0.05)$, a post hoc test (Tukey's test) was carried out for each plot except for decomposed granite soil and sea sand. For decomposed granite soil and sea sand, the Steel-Dwass test or Games-Howell test was conducted, respectively. 
In the present study, Spearman's rank correlation coefficients were determined to assess correlations between variables. To determine the correlation between inoculum potential and quantity of DNA, data sets including a zero value were eliminated as outliers.

All statistical analyses were conducted using R software version 3.6.1 and base packages ${ }^{31}$.

\section{Data availability}

All data generated or analysed during this study are included in this published article (and its Supplementary Information files).

Received: 12 February 2020; Accepted: 29 January 2021

Published online: 18 March 2021

\section{References}

1. Lapwood, D. H. Factors affecting the field infection of potato tubers of different cultivars by blight (Phytophthora infestans). Ann. Appl. Biol. 85, 23-42 (1977).

2. Sato, N. Sources of inoculum and sites of infection of potato tubers by Phytophthora infestans in soil. Jpn. J. Phytopathol. 46, 231-240 (1980).

3. Nærstad, R., Le, V. H. \& Hermansen, A. Reduced fungicide input in late blight control (REDUCE 2007-2011)-preliminary results from 2007 to 2009. PPO-Spec. Rep. 14, 193-198 (2010).

4. Dowley, L. J. \& O'Sullivan, E. Sporulation of Phytophthora infestans (Mont.) de Bary on the surface of diseased potatoes and tuber to tuber spread of infection during handling. Potato Res. 34, 295-296 (1991).

5. Osawa, H., Akino, S., Araki, H., Asano, K. \& Kondo, N. Effects of harvest injuries on storage rot of potato tubers infected with Phytophthora infestans. Eur. J. Plant Pathol. 152, 561-565 (2018).

6. Lacey, J. The infectivity of soils containing Phytophthora infestans. Ann. Appl. Biol. 56, 363-380 (1965).

7. Drenth, A., Janssen, E. M. \& Govers, F. Formation and survival of oospores of Phytophthora infestans under natural conditions. Plant Pathol. 44, 86-94 (1995).

8. Takada-Hoshino, Y. \& Matsumoto, N. An improved DNA extraction method using skim milk from soils that strongly adsorb DNA. Microb. Environ. 19, 13-19 (2004).

9. Schena, L., Nigro, F., Ippolito, A. \& Gallitelli, D. Real-time quantitative PCR: a new technology to detect and study phytopathogenic and antagonistic fungi. Eur. J. Plant Pathol. 110, 893-908 (2004).

10. Lees, A. K., Sullivan, L., Lynott, J. S. \& Cullen, D. W. Development of a quantitative real-time PCR assay for Phytophthora infestans and its applicability to leaf, tuber and soil samples. Plant Pathol. 61, 867-876 (2012).

11. Hussain, T., Singh, B. P. \& Anwar, F. A quantitative real time PCR based method for the detection of Phytophthora infestans causing late blight of potato, in infested soil. Saudi J. Biol. Sci. 21, 380-386 (2014).

12. Osawa, H. Ecological studies on potato tuber rot infested with Phytophthora infestans and its quantification from soil samples. PSJ Soil-Borne Dis. Workshop Rep. 29, 21-30 (2018) (in Japanese).

13. Murray, M. G. \& Thompson, W. F. Rapid isolation of high molecular weight plant DNA. Nucl. Acids Res. 8, 4321-4325 (1980).

14. Ogram, A., Sayler, G. S. \& Barkay, T. The extraction and purification of microbial DNA from sediments. J. Microbiol. Methods 7, 57-66 (1987).

15. Zhou, J., Bruns, M. A. \& Tiedje, J. M. DNA recovery from soils of diverse composition. Appl. Environ. Microbiol. 62, 316-322 (1996).

16. Nguyen, T. H. \& Elimelech, M. Plasmid DNA adsorption on silica: kinetics and conformational changes in monovalent and divalent salts. Biomacromol 8, 24-32 (2007).

17. Shishido, M., Kubota, I., Ohashi, T. \& Usami, T. Comparison of PCR assays for detection and quantification of Phomopsis sclerotioides in plant and soil. J. Gen. Plant Pathol. 79, 18-27 (2013).

18. Ristaino, J. B., Saville, A. C., Paul, R., Cooper, D. C. \& Wei, Q. Detection of Phytophthora infestans by loop-mediated isothermal amplification, real-time LAMP, and droplet digital PCR. Plant Dis. https://doi.org/10.1094/PDIS-06-19-1186-RE (2020).

19. Akino, S., Takemoto, D. \& Hosaka, K. Phytophthora infestans: a review of past and current studies on potato late blight. J. Gen. Plant Pathol. 80, 24-37 (2014).

20. Wang, P. H. \& Chang, C. W. Detection of the low-germination-rate resting oospores of Pythium myriotylum from soil by PCR. Lett. Appl. Microbiol. 36, 157-161 (2003).

21. Brierley, J. L., Stewart, J. A. \& Lees, A. K. Quantifying potato pathogen DNA in soil. Appl. Soil Ecol. 41, 234-238 (2009).

22. Andrivon, D. Dynamics of the survival and infectivity to potato tubers of sporangia of Phytophthora infestans in three different soils. Soil Biol. Biochem. 26, 945-952 (1994).

23. Levy-Booth, D. J. et al. Cycling of extracellular DNA in the soil environment. Soil Biol. Biochem. 39, 2977-2991 (2007).

24. Lorenz, M. G. \& Wackernagel, W. Bacterial gene transfer by natural genetic transformation in the environment. Microbiol. Rev. 58, 563-602 (1994).

25. Lacey, J. The role of water in the spread of Phytophthora infestans in the potato crop. Ann. Appl. Biol. 59, 245-255 (1967).

26. Lacey, J. The distribution of healthy and blighted tubers in potato ridges. Eur. Potato J. 9, 86-98 (1966).

27. Japan Meteorological Agency. Past weather data at Obihiro in August 2018. Preprint at https://www.data.jma.go.jp/obd/stats/etrn/ view/daily_s1.php?prec_no $=20 \&$ block_no $=47417 \&$ year $=2018 \&$ month $=08 \&$ day $=\& v i e w=p 1(2018)$.

28. Fry, W. Phytophthora infestans: the plant (and R gene) destroyer. Mol. Plant Pathol. 9, 385-402 (2008).

29. Caten, C. E. \& Jinks, J. L. Spontaneous variability of single isolates of Phytophthora infestans. I. Cultural variation. Can. J. Bot. 46, 329-348 (1968).

30. Sato, E., Goto, K., Min, Y. Y., Toyota, K. \& Suzuki, C. Quantitative detection of Pratylenchus penetrans from soil by using soil compaction and real-time PCR. Nematol. Res. 40, 1-6 (2010).

31. R Core Team. R: A Language and Environment for Statistical Computing (R Foundation for Statistical Computing) https://www.Rproject.org/ (2019).

\section{Acknowledgements}

The authors thank Dr. Atsuhiko Kushida (Hokkaido Agricultural Research Center) and Dr. Koji Kageyama (Gifu University) for useful advice regarding DNA extraction. This work was supported by JSPS KAKENHI Grant Number JP19J10787. 


\section{Author contributions}

H.O., N.S., S.A. and N.K. designed the study. H.O., N.S., H.A., Ke.A. and Ko.A. contributed to the experiments. H.O. wrote the manuscript, and all authors reviewed the manuscript.

\section{Competing interests}

The authors declare no competing interests.

\section{Additional information}

Supplementary Information The online version contains supplementary material available at https://doi.org/ 10.1038/s41598-021-85492-z.

Correspondence and requests for materials should be addressed to H.O. or S.A.

Reprints and permissions information is available at www.nature.com/reprints.

Publisher's note Springer Nature remains neutral with regard to jurisdictional claims in published maps and institutional affiliations.

(c) (i) Open Access This article is licensed under a Creative Commons Attribution 4.0 International License, which permits use, sharing, adaptation, distribution and reproduction in any medium or format, as long as you give appropriate credit to the original author(s) and the source, provide a link to the Creative Commons licence, and indicate if changes were made. The images or other third party material in this article are included in the article's Creative Commons licence, unless indicated otherwise in a credit line to the material. If material is not included in the article's Creative Commons licence and your intended use is not permitted by statutory regulation or exceeds the permitted use, you will need to obtain permission directly from the copyright holder. To view a copy of this licence, visit http://creativecommons.org/licenses/by/4.0/.

(C) The Author(s) 2021 